\title{
Climate Justice and Historical Responsibility
}

Ever since the 1992 Rio Declaration, global environmental diplomacy has revolved around the principle of "common but differentiated responsibilities". The principle asserts that, while all states should contribute to tackling the challenges of climate change, developed states should bear a greater share of the burdens than developing states. The legal documents that affirm the principle give two reasons for this differentiation of burdens amongst states. The first is historical: developed states bear a greater causal responsibility for global warming insofar as they have emitted greater amounts of greenhouse gases (GHGs) in the past. The second reason appeals to considerations of wealth: developed states are better able to bear burdens in adjusting to climate change in view of their greater levels of wealth. ${ }^{2}$

Most normative political theorists agree that both of these reasons have some weight in justifying differentiated responsibilities amongst states in tackling the challenges of climate change. ${ }^{3}$ However, there is disagreement about the weight we should assign to each reason, and therefore, also, about how exactly responsibilities for tackling climate should be

\footnotetext{
${ }^{1}$ See Principle 7 of the Rio Declaration on Environment and Development (1992), Article 3 of the United Nations Framework Convention on Climate Change (UNFCCC) (1992) and Article 10 of the Kyoto Protocol (1997). I am indebted to Caney $(2005,773)$ for these references.

${ }^{2}$ The historical reason and the wealth-based reason are especially evident in Principle 7 of the Rio Declaration and in the Preamble of the UNFCCC.

${ }^{3}$ For leading contributions that emphasise both history and wealth as grounds for climate duties, see Caney (2009, 243; 2010, 218), Shue (1999, 534-7) and Page (2011, 427).
} 
differentiated between states. This article argues that the debate over the relative importance of history and wealth for differentiating climate duties should be sensitive to a broader institutional issue that has been relatively neglected in the climate justice debate. This is the issue of whether states have so far interacted with each other within institutions of global governance, including, but not exclusively, institutions of global climate governance, that are sufficiently legitimate for historical duties to arise.

To highlight the relevance of background institutions of governance for the emergence of historical duties, I draw on a tradition of political thought that may, at first sight, seem distant from climate justice: the social contract tradition, in particular, John Rawls' contribution to that tradition. A central idea in that tradition is that private transactions between persons cannot give rise to certain normative consequences, in particular, to rights to property, if these transactions occurred outside of a context regulated by a just "basic structure" of political and social institutions (Rawls 2005, 257-288). This article employs a parallel claim at the global level - namely, that states have interacted in the absence of legitimate institutions of global governance, including institutions of global climate governance - in order to argue that (a) the past emissions of GHGs in virtue of which many developed states have acquired historical duties are restricted to the more recent past than has hitherto been recognized in the literature and (b) the current global distribution of wealth is not a just benchmark relative to which all states must make equal sacrifices in tackling climate change. According to what I will call the "institutional view" of climate duties, state responsibilities for tackling climate change at present must mainly be differentiated on grounds of wealth, but will, in future, become increasingly differentiated on grounds of history, assuming that arguably legitimate institutions of global climate governance are now falling into place. 
The article begins by distinguishing two historical arguments for differentiating between the climate duties of states. These arguments assign greater climate duties to some states than others on grounds of unjust enrichment and unjust inheritance, respectively. The article then turns to Rawls' contribution to the social contract tradition in order to draw out the rationale that I use to develop the institutional view of climate duties. The institutional view consists of two main claims. The first is the pre-institutional liability claim. I show that the pre-institutional liability claim prevents the two historical arguments from establishing both what I call a "strong" historical position, according to which excessive emissions reaching into the remote past can ground climate duties today, and a "moderate" historical position, according to which excessive emissions only since the emergence of a scientific consensus on climate change can ground climate duties today (as I explain below, I assume scientific consensus begins from 1990). The pre-institutional liability claim allows us to endorse only what I call a "weak" historical position, according to which some, and possible many, states cannot be held liable for excessive emissions until legitimate institutions of global climate governance promulgated their emission duties to them (a period that begins, as I explain below, from 2008). The weak historical position does not imply, I emphasise, that developed states do not have greater climate responsibilities than developing states. On the contrary, I show how the second key claim of the institutional view, namely, the preinstitutional wealth claim, supports the conclusion that developed states have greater climaterelated responsibilities, at least insofar as it implies that these states cannot assert a legitimate title to their greater wealth as an objection to their greater responsibilities.

Before proceeding, let me point out that the relevance of the institutional view I develop in this article is not restricted to climate-related duties. The institutional view is a general view about the institutional conditions that must be in place before states can acquire certain duties in virtue of the policies they have pursued in the past and thus has implications 
for whether states can acquire duties in virtue of past policies beyond those relating to climate change, such as, for example, the trade policies that they adopted during periods of history in which there were no legitimate institutions of governance regulating trade. This article will not explore these further implications, however, but will keep its focus on the context of climate change.

\section{Two Historical Arguments}

It is now widely accepted that GHG emissions contribute to global warming, and thereby alter the earth's climate in ways that can cause significant harm to many individuals. Global warming leads to extreme weather events, such as flooding, hurricanes and draughts, causing death, destruction, loss and damage to property on a large scale (IPCC, 2014). One controversial issue the global community must address concerns the maximum threshold of GHGs it can release into the atmosphere. This is not just an empirical issue, but a normative issue, because resolving it depends on the harm that the potential victims of climate change can reasonably be subjected to so that others can acquire benefits from emissions-generating activities (Caney 2012, 256). ${ }^{4}$

This article does not address the threshold question, but a distinct question that needs answering along with the threshold question, which concerns fair burden sharing in tackling climate change. I will focus on one main type of burden that states must bear, namely, undertaking costly mitigation efforts - e.g. costly reductions in emissions of GHGs, or

\footnotetext{
${ }^{4}$ Environmental diplomacy has tended to address the threshold question in terms of the maximum increase in global average temperature that GHG emissions should be allowed to cause. The 2015 Paris Agreement set a goal to limit warming to well below 2 degrees Celsius above pre-industrial levels.
} 
increases in carbon sinks - that collectively help to ensure that the global amount of emissions remains beneath the maximum threshold.

Views of fair burden sharing amongst states in the climate change context are historical to the extent that they maintain that duties to contribute to tackling climate change arise as a result of the different amounts of GHG emissions that states have undertaken in the past. I will call duties to contribute to tackling climate change that are justified by reference to historical emissions, historical climate duties. Note that historical climate duties are instances of a particular type of duty - namely, special duties - i.e. duties that arise for actors in virtue of particular transactions they have engaged in. For example, the duty to compensate a person one has harmed is a special duty since it arises from the fact that one has undertaken a particular "transaction", namely, that of harming another person. By contrast, general duties are duties that are held by actors merely in virtue of their being members of the same moral community as the corresponding rights-bearers (e.g. the duty to assist people who face life-threatening emergencies). ${ }^{5}$

Different historical views of burden sharing give different reasons for why past emissions can give rise to historical climate duties in the present. Here I summarise the two most sophisticated arguments in the literature:

(a) Unjust enrichment. States acquire historical climate duties if they have been enriched as a result of unjustly excessive emissions undertaken by past actors (Page 2011; 2012).

(b) Unjust inheritance. States acquire historical climate duties if they have inherited benefits from past actors who undertook unjustly excessive emissions (and who thus

\footnotetext{
${ }^{5}$ For a discussion of the distinction between special and general duties see Seglow (2013).
} 
originally owed those benefits to others in compensation for their unjustly excessive emissions) (Duus-Otterström, 2014). ${ }^{6}$

Both arguments assume that past actors had a duty to restrict their emissions to a certain share of emissions but differ in a subtle way as to why their past breaches of that duty gives rise to historical climate duties on the part of states in the present. For the unjust inheritance argument, this is because the past actors who breached their emissions duties themselves thereby incurred an original duty of compensation, which duty deprived them of ownership rights over the resources they owed in compensation. Assuming that this original duty of compensation was not discharged, these past actors did not have a right to bequeath the resources they originally owed to others. States can therefore be required to contribute to tackling climate change in the present in proportion to the amount of benefits they have unjustly inherited from those past actors. The range of states to whom the unjust inheritance argument assigns historical duties is therefore restricted to states that inherited from past excessive emitters.

\footnotetext{
${ }^{6}$ I will not discuss another argument one might appeal to in order to justify historical climate duties, namely, the "polluter pays" argument according to which it is the actor who emitted excessively who must bear climate-related duties. The polluter pays argument is more restricted in its relevance than the two arguments just summarised because it cannot explain why breaches of emissions duties by actors give rise to historical climate duties for actors other than the polluter, who live at a later point in history. Furthermore, although the polluter pays argument can be used to justify climate-related duties for polluters who are still alive, it will encounter the same problem, when used in that way, that the institutional view raises for the unjust enrichment and unjust inheritance arguments.
} 
According to the unjust enrichment argument, by contrast, past breaches of emissions duties can give rise to historical duties for states even if these states did not inherit resources from the past actors who undertook those breaches. It is enough for historical duties to arise that states have benefitted from past breaches of duty. For example, a state may have benefitted by engaging in trade with another state that inherited resources that were produced through unjustly excessive emissions. The range of states to whom the unjust enrichment argument assigns historical duties is thus likely to be broader than the unjust inheritance argument. $^{7}$

In what follows, I develop a view that suggests that the extent to which these two historical arguments should determine fair burden sharing in the climate change context is more limited than currently recognized in the literature. I call this the institutional view because it emphasises that certain kinds of normative consequences can arise for actors only if their interactions have been regulated within legitimate institutions of governance. The institutional view allows that past breaches of emissions duty can give rise to present-day historical duties in virtue of the considerations highlighted by the unjust enrichment and unjust inheritance arguments. However, it maintains that some, if not many, past breaches of emissions duties only give rise to present-day historical climate duties if they were undertaken within legitimate institutions of global climate governance. The institutional view thus does not directly oppose the two historical arguments but takes a stand on the conditions

\footnotetext{
${ }^{7}$ An additional noteworthy difference between Page's unjust enrichment argument and DuusOtterström's unjust inheritance argument is that whereas Page defends historical duties on the ground that states have been made counterfactually better off by past excessive emissions (i.e. better off than they would have been), Duus-Otterström does not place any weight on this counterfactual. See Page (2012, 16-18).
} 
under which they can reasonably be applied. I will argue that a reasonable application of either historical argument generates more limited historical climate duties than the climate justice literature has tended to endorse.

\section{Social Complexity in the Social Contract Tradition}

It will be helpful if I formulate the overarching claim of the institutional view in negative terms as follows: "pre-institutional" action, or action undertaken outside of legitimate institutions of governance, cannot give rise to certain normative consequences, specifically to certain rights to property and to special duties to compensate for certain breaches of duty. This section draws out a rationale for this overarching claim from John Rawls' contribution to the social contract tradition.

The rationale that I draw from Rawls focuses on the effects of social complexity on the capacities of actors to acquire certain kinds of morally relevant knowledge. By "social complexity", I mean an evolving condition of a society in which its members affect each other's outcomes in increasingly significant ways along multiple and interconnected causal pathways that are difficult to discern - for example as a result of the use of increasingly sophisticated technologies and specialised modes of production. Social complexity makes it difficult for actors to obtain the facts that they need in order to tell what their rights demand of others from one situation to the next and whether those rights are actually being fulfilled at least when these actors lack political institutions that promulgate to them what their rights are and that monitor whether those rights are being fulfilled.

The knowledge-undermining effects of social-complexity prevents pre-institutional action from establishing certain rights to property and special duties to compensate for certain breaches of duty. To see why, it is helpful to consider Rawls' critique of John Locke's argument to the contrary in Chapter 5 of the Two Treatises of Government (1689) where 
Locke maintains that transactions in a "state of nature" can justify certain property rights, in particular, a "disproportionate and unequal possession of the earth" (1988, Bk. 2, Sect. 50).

Locke presents us with an idealized history of pre-institutional action - a history of transactions between individuals that Locke imagines could have taken place and in which everyone fulfils basic natural duties to each other (such as the duty to respect each other's physical security and fair share of natural resources). The first stage of this idealized history consists of a barter economy in which general compliance with the natural duty to refrain from accumulating resources in excess of what one could use (the so-called "spoilage proviso") limits the extent of material inequality between persons (Bk. 2, Sect. 37). The second stage begins with the introduction of money, a convention to which all persons tacitly consent (Bk. 2, Sect. 47). This convention allows individuals to accumulate resources without contravening the spoilage proviso and thus eventually sanctions vast material inequality between them. Locke believes that if vast material inequality could have emerged from an ideal history, then we can conclude that the vast material inequality that has actually emerged is not necessarily unjust. ${ }^{8}$

Rawls' critique is that persons cannot acquire vastly unequal property rights from private transactions even under the idealized conditions Locke assumes. The basic reason for this is that private transactions can only generate rights to property if they are carried out against certain background social conditions that Locke does not stipulate as part of his idealized history. Rawls writes that if distributions of property are to evolve legitimately, "[t]he existing wealth," which is exchanged in the transactions, "must have been properly acquired" in the first place, and, furthermore, "all must have had fair opportunities to earn income, to learn wanted skills and so on" $(2005,266)$. However, as Rawls explains, there will

\footnotetext{
${ }^{8}$ On Locke's idealized history as a method of justification, see Rawls $(2008,131)$.
} 
be a point in Locke's idealised history after which "the conditions of free and fair agreements no longer hold" $(2005,266)$. This is particularly evident if we imagine Locke's history unfolding over several generations. A point will inevitably come after which some individuals will have inferior starts in life to others, if only as an unintended consequence of many innocent exchanges conducted during earlier periods. Some of these individuals will face significant disadvantages in bargaining power when they carry out commercial exchanges, for example when negotiating wages with employers. These exchanges would thus seem to be unfair and may not be genuinely free. Also, whatever wealth employers acquire in these transactions may not be legitimately theirs and this undermines the legitimacy of further transactions in which unjustly acquired wealth is exchanged.

It is crucial to observe the exact way in which Rawls' critique shows us that the preinstitutional account cannot generate certain rights to property. To see this, notice the following farfetched possibility. It might be possible that private transactions can generate rights to property in the absence of legitimate institutions because it may be possible for individuals to act in ways that maintain the background conditions that are necessary for their transactions to be legitimate without their actually establishing political institutions for this purpose. For example, individuals might devise and follow rules for how exactly they should adjust their possessions from one moment to the next (for example, how many of their possessions they should give away and to whom) so that it would be true of their remaining possessions, that these would have been "properly acquired", such that further transactions in which those possessions are exchanged would be legitimate. It may also be possible for individuals to devise and follow rules as to how exactly they must adjust the terms of their specific transactions so that they do not end up benefitting from any past disadvantages suffered by those with whom they are exchanging. However, as Rawls points out, such rules would have to be enormously complex and would "exceed the capacity of individuals to 
grasp and follow them with sufficient ease" $(2005,266)$. What Rawls is saying, here, is that social complexity makes it impossible for individuals to tell how exactly they should adjust their possessions and the terms of their transactions with others in order to ensure that their possessions remain their rightful property over time.

Let me now expand Rawls' critique of Locke in one important respect. This involves pointing out that the facts that a given person needs in order to tell whether her own or other people's possessions are rightful are not restricted to non-moral facts about whether the correct criteria for the acquisition of rightful property have been fulfilled. She would also need to know the nature of the criteria themselves. While one might be reasonably confident about the soundness of Rawls' criteria - i.e. that transactions must be undertaken under conditions that render them free and fair and that the wealth exchanged in transactions must have been properly acquired in the first place - how exactly these criteria must be spelled out in detail is likely to depend on facts that are too difficult for individuals to obtain under conditions of social complexity without legitimate institutions. Take the criterion that existing wealth must have been properly acquired in the first place. Presumably, this criterion would govern how persons may appropriate natural resources. However, it is difficult to determine what exactly that criterion should be, at least assuming that the correct way of specifying fair appropriation of natural resources is something that will turn, in part, on the long-term economic consequences of one or another way of specifying it. Thus, even on the barely conceivable assumption that everyone could gather the facts they would need in order to discern whether others had complied with some proposed criterion for governing the appropriation of natural resources, it is hard to see how all can know that the proposed criterion is itself correct.

Let us now shift from observing how the epistemological challenges posed by social complexity prevent pre-institutional actions from generating rights to property to observing 
how they prevent pre-institutional actions from generating duties to compensate for certain breaches of duty. To see this vividly, consider a farmer whose life has stretched from the second stage of Locke's idealized history into the subsequent period of legitimate institutional governance. Suppose that this farmer never committed any obvious breaches of duty during the pre-institutional era: he never murdered, enslaved or stole from anyone. However, a newly established Committee on Historical Injustice has discovered a problem with his past record of land-use. It turns out that the farmer used a small parcel of land that was, in fact, the rightful property of his neighbor. Let us assume that the farmer could not have obtained the facts that would have established that he was in breach of his duty not to use his neighbor's land. He would have needed to know that his neighbor's ancestors, rather than his own, were the ones who had fairly appropriated the land in the first place, and that, instead of its falling into the rightful hands of his neighbour, various accidents of history had brought it into his hands instead.

The fact that the farmer cannot reasonably be expected to have known that he was in breach of his duty to respect his neighbour's property has important implications for the two historical arguments that I distinguished in the previous section (here we must imagine applying the arguments in order to establish that other persons at some later point in history have acquired historical duties as a result of the farmer's having breached his duty to respect his neighbor's property). First, if the farmer did not breach his duty to his neighbour culpably -i.e. if he cannot reasonably be expected to have known that he was breaching his duty - this may mean that his descendants (or anyone else who has been enriched by the farmer's breach of duty) do not have a duty to compensate on grounds of unjust enrichment. This is so, at least, if we believe that a duty to compensate on grounds of unjust enrichment stems from a requirement to disassociate from past wrongdoing. If the farmer was not culpable in breaching his duty to his neighbour, then his descendants have not been enriched by past 
wrongdoing and therefore have not acquired a duty to compensate for that historical breach.

The second implication is relevant for the unjust inheritance argument. To see this implication, we must consider whether the farmer's having appropriated his neighbour's land generated an original duty of compensation for the farmer. While we may be prepared to accept that an original duty arose for the farmer had he culpably appropriated his neighbour's land, the nature of the duty that arises from non-culpable appropriation is more subtle. To get at this duty, it helpful to imagine, first, that the farmer did not benefit in any way from his non-culpable breach of duty to his neighbour. Suppose, for example, that birds consumed so many of the crops on the over-appropriated parcel of land, that the farmer effectively gained nothing from having non-culpably over-appropriated it. Under this circumstance, it seems harsh to conclude that the farmer has an original duty of compensation to his neighbour for his having non-culpably appropriated that land. Imagine, next, that the farmer did benefit from his non-culpable over-appropriation of his neighbour's land. The most natural reaction is now that he has a duty to compensate his neighbour in proportion to the extent to which he benefitted from the over-appropriated land (if he benefitted only very slightly, a duty to provide full value compensation would, again, seem harsh). These judgements reflect the following understanding of the duty that arises from non-culpable over-appropriation: it is a duty to avoid benefiting relative to others from an event that was a matter of fortune (i.e. an event beyond the exercise of deliberative agency). Over-appropriation that is non-culpable is, in a sense, a matter of fortune, and the farmer's duty is such that he must not benefit relative to his neighbour from this piece of fortune.

The reason this second implication of non-culpability is important is that it shows us that we cannot reasonably insist that non-culpable over-appropriators have duties to compensate for any arbitrary advantage they have gained over others, without also insisting that other actors should compensate for other ways in which they might have acquired 
arbitrary advantage. In that case, a proponent of the unjust inheritance argument cannot reasonably restrict duties to compensate to states that have inherited from past actors that non-culpably breached their emissions duties but must assign duties to all states that have acquired arbitrary advantage in any way over other states. The practical implication of this conclusion is that we should shift towards a wealth-based rather than history-based assignment of climate duties.

Let me emphasise an important feature of the rationale for the institutional view I have given in this section. Because the institutional view rests on an epistemological claim regarding the knowledge-undermining effects of social complexity, it only rejects preinstitutional rights of property and pre-institutional duties of compensation to the extent that this is implied by that epistemological claim. This means that the institutional view does not imply that persons can never acquire pre-institutional rights of property or pre-institutional duties of compensation for there may be social circumstances that are so simple that it is relatively easy for individuals to tell what criteria should govern the rightful acquisition of property and whether those criteria are being fulfilled. Furthermore, it may be so evident with respect to some duties that persons are acting in breach of them, that those persons can reasonably be expected to know this even under conditions of social complexity. This may be the case, for example, with respect to duties to refrain from murder or enslavement. Persons can therefore acquire special duties to compensate even if they murdered or enslaved in the absence of legitimate institutions governance. In short, the institutional view is not a Hobbesian view to the effect that there can never be any pre-institutional rights and duties, but a nuanced view according to which some pre-institutional rights and duties can arise, 
while others cannot, depending on the context. ${ }^{9}$

\section{The Pre-Institutional Liability Claim}

I now restate the two main claims of the institutional view in a form that makes them relevant for our assessment of the unjust enrichment and unjust inheritance arguments in the climate

\footnotetext{
${ }^{9}$ The previous five paragraphs explain the difference between the case I make for the institutional view and Carmen Pavel's case for her "legal conventionalist" view, which also maintains that it makes a difference to actors' liabilities whether they undertook emissions outside of legitimate institutions $(2016,238)$. Pavel's case points to the fact that emissions
} duties depend on a balancing judgment between the competing interests of the would-be emitter against the interests of the would-be victim of emissions. The case I make emphasises a more abstract consideration (within which the need for balancing that Pavel points to is relevant), namely the epistemological consideration that past actors outside of legitimate institutions cannot reasonably be expected to have known that they were breaching their emissions duties. Emphasising the epistemological consideration helps us to see that it is not the fact that emissions duties depend on a balancing judgment per se that explains why liabilities are affected by whether emissions took place outside of legitimate institutions but that they depend on any complex factor that imposes burdens on our capacity to identify our emissions duties. This epistemological consideration also helps to explain why we should reject the Hobbesian view that past actors are immune from liability regardless of how excessively they emitted. This is because actors who undertook extremely high emissions clearly can be expected to have known that they were breaching their emissions duties. I am indebted to Pavel's article for helping me appreciate that the need for balancing is one among several possible burdens of judgement that actors face in identifying their emissions duties. 
justice debate. The first of these two claims can be stated as follows:

\section{The pre-institutional liability claim}

(a) For states to acquire historical climate duties in virtue of being enriched by, or inheriting from, past actors who breached emissions duties, those past actors must reasonably be expected to have known that they were breaching their emissions duties; ${ }^{10}$ and

(b) Past actors cannot reasonably be expected to have known that they were breaching their emissions duties merely insofar as they knew the science of anthropogenic climate change.

In what follows, I defend the pre-institutional liability claim against objections. Before I turn to this task, I want to show how the claim is at the centre of a controversy between three positions one can adopt with respect to the historical range of past excessive emissions that can give rise to historical climate duties in the present.

Suppose, to begin with, we reject part (a) of the pre-institutional liability claim. In that case, we should adopt what I will call a strong historical position. Because this position says that past excessive emissions can give rise to historical duties even if past emitters cannot reasonably be expected to have known that they were emitting excessive, it implies that historical duties can arise from past emissions that took place far back in the past, even before the era of scientific consensus on anthropogenic climate change.

\footnotetext{
${ }^{10}$ Past actors "cannot reasonably be expected to have known" that they were breaching emissions duties if they faced significant burdens of judgment in identifying their emissions duties. On the burdens of judgement in the context of climate justice, see Long (2011).
} 
Suppose, next, we accept part (a) and reject part (b) - i.e. suppose we believe that historical climate duties can only arise from past emissions that were undertaken culpably and that past actors can reasonably be expected to have known that they were breaching emissions duties merely insofar as they knew the relevant climate science. In that case, we should adopt a moderate historical position. The moderate historical position extends the period over which past excessive emissions can give rise to present-day historical duties only as far back as to the beginning of the era of scientific consensus on anthropogenic climate change. Although my argument does not depend on precision over when exactly this era begins, I will assume, following others, that it begins with the first report of the Intergovernmental Panel on Climate Change (IPCC) - i.e. 1990 - in which the IPCC states with certainty that "emissions resulting from human activities are substantially increasing the atmospheric concentrations of greenhouse gases."11 The moderate historical position implies, then, that historical duties arise from all excessive historical emissions after 1990.

Suppose, finally, we accept both parts (a) and (b) of the pre-institutional liability claim. In that case, we should adopt a weak historical position. According to this position, it does not automatically follow from the fact that a past actor knew the relevant climate science that this actor can reasonably be expected to have known that she was breaching her emissions duties. By implication, therefore, we cannot assume that historical duties arise from all excessive historical emissions after 1990. A proponent of the weak historical position would say that the conclusion that historical climate duties arise from past excessive emissions is only secure for all past excessive emissions from the moment after which

\footnotetext{
${ }^{11}$ Houghton (1990) cited in Kingston $(2014,4)$. For a discussion of possible dates after which the negative consequences of historical emissions were sufficiently foreseeable to warrant liability for those who undertook them, see Gosseries (2004, 42); cf. Jamieson (2001).
} 
legitimate institutions of global climate governance promulgated emissions duties to states, since it is only after this moment that we can confidently say of past actors that they should have known that they were breaching their emissions duties. As I explain below, this period begins in 2008 at the inception of the first reporting period set by the Kyoto Protocol.

In the following section, I defend part (a) of the pre-institutional claim and thus show that we must reject the strong historical position. In the section thereafter, I defend part (b), and thus show that we must reject the moderate historical position. The implication of these arguments is that we should accept the weak historical position.

\section{Against the Strong Historical Position}

My objection to the strong historical position will take the form of rebutting three arguments that aim to reject part (a) of the pre-institutional liability claim - the claim that past actors must reasonably be expected to have known that they were breaching their emissions duties before their breaches can give rise to later duties of compensation.

(i) Enrichment from non-culpable injustices. According to Page (2012), whether past excessive emissions can give rise to present historical duties on grounds of unjust enrichment does not depend on whether past actors undertook those injustices culpably. That past emitters could not have known that they were breaching their emissions duties is therefore no reason for denying that their emissions can give rise to historical climate duties on grounds of unjust enrichment. My reply to this suggestion questions whether it is plausible to extend the unjust enrichment argument so that it covers enrichment from past injustices independently of past culpability. Consider the following thought-experiment. Suppose Region A today benefits from global warming that resulted from past excessive emissions undertaken before the era of scientific consensus on climate change. For example, we might assume that global warming has raised the local temperature in Region A so as to improve its agricultural yields. 
Meanwhile, in Region B, agricultural yields have improved to the same extent, though not as a result of global warming, but due to a fortunate reduction in local agricultural pests. It seems counter-intuitive that people in Region A, who have been enriched in virtue of past excessive emissions, owe special duties to compensate for global warming, whereas people in Region B do not. Other things equal, it seems more reasonable to maintain that both regions have the same duties. This suggest that our concern that we must avoid enrichment from past injustice is not so broad as to require us to relinquish benefits from past injustices as such, but more narrowly focused on the importance of distancing ourselves from past culpability (perhaps out of solidarity with the victims of the culpable acts in question). ${ }^{12}$

I have just argued that a proponent of the unjust enrichment argument cannot establish historical duties merely on account of past injustices, and hence cannot, for that reason, reject part (a) of the pre-institutional liability claim. I now reject two arguments that proponents of the unjust inheritance argument might use to reject part (a).

(ii) Strict liability. The first argument draws an analogy to tort law (Neumayer 2000, 188). ${ }^{13}$ Tort law does not seem obviously objectionable in the few instances in which it assigns special duties of compensation to actors who cannot reasonably be expected to have known that they were breaching duties to others. For example, tort law employs a standard of

${ }^{12}$ I thus agree with David Miller's observation $(2009,136)$ : “Global warming is not like slavery, where there was a clear historic wrong that required, and may still require, redress." ${ }^{13}$ Stephen Gardiner also seems to support a strict liability argument: "If I accidentally break something of yours, we usually think I have some obligation to fix it, even if I was ignorant that my behavior was dangerous" $(2011,416)$. I believe Gardiner implausibly analogizes the harms of excessive emissions to highly local interactions between private actors where regulation by anything other than a strict liability principle is impractical. 
strict liability to persons if the dangerous animals they own unforeseeably cause harm to others, or to manufacturers, whose malfunctioning products cause unforeseeable harm. Similarly, it might be argued that past actors who undertook excessive emissions prior to the emergence of scientific consensus on climate change can also be held liable for this despite the fact that their emissions caused unforeseeable harm. Those past actors therefore owed compensation, and whomever has inherited resources form them have a duty to relinquish their inherited resources to the extent that they were original owed in compensation.

This argument is unconvincing: it seems unfair to hold actors to a standard of strict liability if they have never been informed that this is the standard they are being held to. As Mathias Risse writes $(2012,199)$, strict liability "should not apply without the affected individuals being aware of it. Only then can they choose whether to participate in the relevant activities" (cf. Kingston 2014; Moellendorf 2012). Even if we accept that strict liability may be used in some cases of tort law, the analogy to tort law thus fails because a legitimating condition for strict liability - the advance warning of its application - was not fulfilled in the case of past generations that undertook excessive emissions.

(iii) From harm to appropriation. Proponents of the unjust inheritance argument can shift our focus from the fact that past excessive emissions may have unjustly harmed others to the fact that they unjustly appropriated other people's "fair shares" of emissions. In contrast to his having unjustly harmed others without knowing it, the fact that an actor unjustly appropriated from others without knowing it, does not seem to absolve him of special duties of compensation. Duus-Otterström gives this amusing example:

Suppose you and I are shipwrecked on opposite sides of an island. On the island is a meadow where rare flowers grow...Unaware of your presence, I dig up the plants and move them to my hut. Then you and I meet. It seems that you now have a reasonable 
compliant against me: I appropriated all of the flowers, leaving none for you. Yet I was not aware of doing anything wrong in digging up the plants $(2014,458)$.

Let me make two points about this example that draw on my earlier discussion of the example of the farmer. First, the relevant fact that gives me a special duty of compensation is not my act of over-appropriation as such but the fact that my over-appropriation gave me benefits. (Imagine that some birds snatched the flowers I over-appropriated just as I picked them, so that I couldn't bring them back to my hut. If I had no clue about your existence at the time of picking the flowers, attributing a special duty of compensation to me would seem unfairly punitive.) In parallel, we should conclude that past actors who could not reasonably have been expected to know that they were emitting excessively did not acquire original duties of compensation merely on account of their having undertaken excessive emissions.

The second point concerns a revised version of the unjust inheritance argument that justifies historical climate duties not by appealing to the fact that past actors undertook excessive emissions as such, but that they benefitted from undertaking excessive emissions. As I argued earlier, the claim that non-culpable over-appropriators must compensate if and to the extent that they have benefitted from over-appropriation rests on the deeper assumption that persons must compensate others if and to the extent that they have enjoyed an arbitrary advantage over them. The revised version of the unjust inheritance argument cannot therefore coherently assign a duty of compensation only to non-culpable over-appropriators (and thus to whomever inherited from them) but must also assign duties of compensation to persons who enjoy arbitrary advantage more generally. A parallel conclusion to draw is that we should not assign climate related duties to states according to the emissions records of the past actors from whom they have inherited, but according to their different levels of arbitrary advantage over other states. Our best way to follow through on that principle is to assign 
climate related duties according to differences in wealth, rather than differences in historical emissions. $^{14}$

\section{Against the Moderate Historical Position}

The moderate historical position accepts part (a) but rejects part (b) of the pre-institutional liability claim. It accepts that past actors must reasonably be expected to have known that they were undertaking excessive emissions in order for their emissions to give rise to historical duties in the present, but it asserts that past actors could reasonably be expected to have known this so long as they knew the science of climate change (which, as I stipulated earlier, I assume they did after 1990). All excessive historical emissions, after that point, thus give rise to associated historical duties in the present.

The core problem with the moderate historical position is that it overlooks the epistemological challenges posed by social complexity. Recall, our example of the farmer at the end of the second stage of Locke's idealized history. It seemed unreasonable to regard the farmer as culpable for appropriating a parcel of neighbor's land because he could not know all the facts pertaining to the history of its transfer down the ages. This same reasoning applies to states that undertook excessive historical emissions after 1990. We cannot assume

\footnotetext{
${ }^{14}$ My point here is related to Simon Caney's point that we should not adopt a method of "isolation" but "integration" when identifying climate-related duties. Caney believes that it is arbitrary to focus our distributive justice concerns only on emissions rights in isolation from how other resources are distributed between the states. I am arguing that it is arbitrary to focus our distributive justice concerns only on the extent to which states may have benefitted from their own non-culpable excessive emissions as opposed to the extent they have benefitted from other kinds of events for which no one can be held more generally.
} 
that they were culpable for their excessive emissions merely insofar as they knew the relevant climate science, for it may be the case that social complexity undermined their capacity to obtain the facts they needed in order to tell that they were breaching their emissions duties.

A proponent of the moderate historical position might reply to this criticism by acknowledging that social complexity can make it too difficult to tell whether some amounts of emissions would breach emissions duties, but still argue that the amounts of emissions that all developed states were in fact undertaking post-1990 did not fall into this grey area. They were so high as to be obviously excessive. Acknowledging the fact of social complexity thus does not warrant a departure from the moderate historical position: we should still say that all excessive emitters post-1990 were culpable for their excessive emissions and that their excessive emissions gave rise to historical duties on the part of states that were enriched by or inherited from them.

This reply is, in my view, too sweeping. To see why, it is helpful to consider the record of a given developed state more closely. Consider the UK's domestic policy record on emissions, after the emergence of consensus on climate science, stands up to plausible accounts of its emissions at the time. The UK parliament did not remain passive in response to the emerging climate science. It passed the Electricity Act (1989), which established the Non-Fossil Fuel Obligation (NFFO) - an obligation for companies licensed to distribute electricity to purchase electricity from nuclear and renewable energy providers. The additional costs of electricity these companies paid was covered by a Fossil Fuel Levy (FFL) - a tax on electricity consumption applied to all electricity consumers. The Electricity Act thus inaugurated the UK's market-based approach to emissions reduction that was to be expanded and amended in the 1990s and 2000s, for example, with the addition of the 1996 Landfill Tax and the 2001 Climate Change Levy (which replaced the FFL). Partly as a result of these domestic policies, the UK was able to reduce its greenhouse gas emissions from an 
above EU-15 average in 1990 to the EU-15 average in $2005 .^{15}$

Does this policy record amount to an obvious breach of the UK's emissions duties? That depends, of course, on what the UK's emissions duties were during that period. Now, according to one prominent account of its emissions duties, the UK was indeed in obvious breach of its emissions duties. This is the account that requires the UK to restrict its emissions to an equal per capita share of the total emissions budget. (The UK's per capita emissions of $\mathrm{CO}_{2}$ stood at 9.3 metric tons in 2000 , well above the majority of other states. ${ }^{16}$ ) However, the equal per capita emissions account is not a plausible account of emissions duties because it disregards a number of morally relevant considerations. ${ }^{17}$ One such consideration is that states cannot be held responsible for the fact that their economies developed in a more fossil-fuel reliant direction than others prior to the era of scientific consensus on climate change. It is thus unreasonable, for example, to assume that the UK should have the same per capita emissions as, say, Switzerland. Another consideration is that states with larger economies may have a right to a greater than equal per capita share of emissions if their having this right increases global economic growth in ways that serve the interests of worse off states. Third, once a state has become aware that it is emitting beyond the amount it ought to emit, it may be entitled to a period of grace in seeking to implement a long-term emissions reduction strategy. Finally, there is the larger background question about

\footnotetext{
${ }^{15}$ I am indebted to Bowen and Rydge $(2011,7)$.

${ }^{16}$ See European Commission (2011).

${ }^{17}$ One powerful objection to the equal per capita emissions account is that it implausibly relies on restricting the concern for distributive equality to the equal distribution of one good in particular, namely $\mathrm{CO}_{2}$ emissions rights. It thus relies on the method of "isolation" criticised by Simon Caney to which I referred in fn. 14 above.
} 
the overall carbon budget that needs to be allocated between states. While the Paris Agreement has set this budget in line with ensuring that global warming remains below 2 degrees Celsius relative to pre-industrial levels, it is difficult to see how the UK could have confidently identified that as the relevant overall carbon budget (and on that basis inferred its own individual emissions entitlement).

These considerations imply that a plausible account of a given state's emissions duties during a given period of history is likely to be a far more complicated affair than is suggested by the equal per capita emissions account. More pertinently for our discussion, they imply that even if the UK might have exceeded its emissions duties post-1990, this may not have been so to the extent that we can reasonably expect the UK to have known that it was in breach of its emissions duties. Its emissions reduction strategy post-1990 may well have complied with a reasonable range of proposals about its climate related duties.

The example of the UK should lead us to endorse the weak historical position, which denies the automatic assumption that states can reasonably have been expected to know that they breached their emissions duties post-1990. Our approach should instead be to evaluate, on a case-by-case basis, whether the domestic policy records of different developed states were in obvious breach of our most plausible accounts of their emissions duties at the time, and we should be prepared to accept that, with respect to a number of developed states such as the UK, this may not have been the case. ${ }^{18}$

Let me now elaborate two practical implications of the institutional view for how we

\footnotetext{
${ }^{18}$ To be clear, there may well be some states who can reasonably be expected to have known that their domestic policy record from 1990 onwards was in breach of their emissions duties. This may apply to the United States, whose per capita emissions in 1990 was more than double that of the UK and then increased until 2000. See European Commission (2011).
} 
should assign historical duties in virtue of past excessive emissions. The first concerns the point in history after which the weak historical position says we can conclude for certain that past excessive emissions have given rise to present-day historical duties. This is the point after which legitimate institutions of climate governance promulgated emissions duties to all states. From this point onwards, we can confidently say that any state that was breaching its emission duties should have known that it was doing so. When exactly was this point in history reached?

The most significant milestone in the history of climate governance, the United Nations Framework Convention on Climate Change (UNFCCC), was negotiated in 1992, and entered into force in 1994. Arguably, the parties to the UNFCCC constitute a legitimate institution of global climate governance. ${ }^{19}$ However, while the UNFCCC set an overall goal to "stabilize greenhouse gas concentrations in the atmosphere at a level that would prevent dangerous anthropogenic interference with the climate system" (Art. 2,) and while it established an institutional framework for achieving that goal by setting up the Conference of the Parties (the supreme body of the UNFCCC), it did not identify the emissions duties of states. That step is taken only by the time of the Kyoto Protocol, adopted in 1997. The first "commitment period" over which the Protocol requires states to comply with their assigned

${ }^{19}$ I follow Buchanan and Keohane's (2006) three-part "complex standard” for the legitimacy of global institutions: (a) minimal moral acceptability, i.e. a requirement that the global institution in question refrain from violating the least controversial human rights, (b) comparative benefit, i.e. the institution is superior to a feasible alternative institution, and (c) integrity, i.e. the institution must behave in line with its own procedures and goals. Arguably, the Parties to the UNFCCC complies with this standard. 
duties is $2008-2012 .{ }^{20}$ So, the point in history from which the weak historical position says we can with certainty attribute culpability for excessive emissions would thus seem to be $2008 .^{21}$

The second practical implication concerns the status of excessive emissions that might take place after the 2015 Paris Agreement. The Paris Agreement has adopted a different format in which to "promulgate" emissions duties to its parties. Rather than collectively assigning emissions reduction targets for different states, the Paris Agreement uses a procedure of self-assigned targets or "nationally determined contributions" that comes into force from 2020. Since the Paris Agreement seems to have retreated from a collective declaration of each state's emissions duties, it may seem as if the institutional view must conclude that a given state's excessive emissions from 2020 onwards shares the same uncertain status (in terms of its giving rise to special duties of compensation) as did excessive emissions from 1990 to the first Kyoto reporting period in 2008. It would be true of any state that emitted excessively in either period that it emitted excessively in the absence of a collective view of its emissions duties.

However, the institutional view would not have that implication. This is because the Paris Agreement does not actually retreat from a collectively settled view of each state's emissions duties, so much as issue that collective view in a different format from how it was

${ }^{20}$ The Kyoto Protocol identifies "assigned amounts" of emissions for states, e.g. it identifies Norway's assigned amount as 1\% above its 1990 level of emissions, and Croatia's as 5\% below its 1990 level of emissions.

${ }^{21}$ Note that the Kyoto Protocol did not assign emissions duties to Non-Annex I Parties, including, for example, China. The institutional view thus implies that we cannot confidently attribute culpability to these states even by the time of the first Kyoto reporting period. 
issued under Kyoto. The Paris Agreement is, in effect, a collective agreement to authorise the self-assigned targets of its members as their emissions duties. There may well be an air of paradox around the fact that an emissions target could have the status of a "duty" if it is selfassigned. But consider this analogy. We do not regard the fact that a person had discretion in determining whether to make a promise, and what promise to make, as a reason for why she lacks a duty to do what she ended up promising to do. There need be no incoherence either, therefore, in regarding self-assigned targets as duties. Note, furthermore, that the Paris Agreement includes a so-called "principle of progression" (Art. 3 9(3)) which requires states to self-assign increasingly more ambitious targets from one reporting period to the next. Given these points, the institutional view would allow us to attribute culpability to states were they to breach their self-assigned emissions targets from 2020 onwards. $^{22}$

Let me conclude this section by considering a objection that a proponent of the moderate position might raise against this weak historical position. According to many observers, some states, in particular, the United States, obstructed the establishment of

\footnotetext{
22 To be clear, I am not endorsing the format in which Paris 2015 promulgated climaterelated duties to states. I acknowledge that Paris 2015 constitutes a weak basis of liability for states and thus raises a difficult question for the institutional view: are states immune from liability so long as they comply with promulgated duties that happen to be weak? The institutional view, recall, is not the Hobbesian view that there can never be any duties outside of those promulgated to states by legitimate institutions. It thus allows that states can be held liable even if they comply with their promulgated duties if they can reasonably be expected to have known that those duties were too weak. Whether this is indeed the case with respect to Paris 2015 is a difficult question that I cannot settle here.
} 
legitimate institutions of climate governance after $1990 .{ }^{23}$ Surely, it is unreasonable that states should escape liability for their excessive emissions if they themselves prevent legitimate institutions from being established and from promulgating their emissions duties to them. Suppose, by way of analogy, that a powerful landowner in the state of nature prevents his community from establishing a political association that could pronounce on the fair division of land. He cannot reasonably appeal to the absence of an institutionally promulgated view of everyone's fair share of land as a defence against liability for his having over-appropriated in the state of nature.

This objection calls for an important supplement to the weak historical position. But note first that the objection actually resonates with the core claim of the institutional view namely, that social complexity undermines the capacity of actors to tell whether their rights are being respected. Assuming that actors have strong reason to avoid a situation that undermines their capacity to determine this matter, they have strong reason to establish legitimate institutions of governance. A proponent of the institutional view should thus endorse the objection and supplement the weak historical position so that it also asserts that states can acquire historical duties in virtue having breached their duty to establish legitimate institutions ("institutional obstruction"). Note, however, that this supplement does not erode the difference between the weak historical position and the moderate historical position. Not all states that emitted excessively after 1990 can be accused of obstructionism.

\section{From History to Wealth}

Having argued that the institutional view restricts the extent to which history can explain why developed states ought to bear greater climate related burdens than developing states, I now

\footnotetext{
${ }^{23}$ For an indictment of US obstructionism in tackling climate change, see Shue $(2014,24)$.
} 
conclude by showing, in outline form, how the institutional view supports the conclusion that developed states should bear greater climate related burdens than developing states on grounds of wealth.

To this end, I now introduce a second key claim the institutional view makes:

The pre-institutional wealth claim: For present-day members of different states to acquire rights to property, they must have appropriated natural resources fairly, and entered into commercial exchange with members of other states against fair background conditions.

I will not rehearse the case for the pre-institutional wealth claim that I made during the discussion of Rawls' critique of Locke. Instead, I want to explain what follows from the preinstitutional wealth claim.

The key observation to make is this. Although the international society of states has interacted for some time within global institutions that execute functions equivalent to the functions of some core domestic political institutions (e.g. the UN General Assembly and Security Council, and the Bretton Woods system of economic institutions - i.e. the IMF, the World Bank, and the WTO) - and even if one conceded that this set of global institutions is legitimate, one would still have to acknowledge the limited historical presence of this set of global institutions. ${ }^{24}$ Because this set of institutions has been in place only for a relative short

${ }^{24}$ An interesting question arises for the institutional view I defend if we assume that these "core" global institutions are not legitimate, namely, whether state actions today generally cannot give rise to later historical duties. This would follow from a Hobbesian view that rejects the possibility that actions outside of legitimate institutions can give rise to duties. As 
period of history, its historical presence is not enough to establish that the current distribution of wealth between states is a fair baseline with which to determine burden sharing in the climate change context. In other words, we cannot assume that the existing distribution of wealth between states is just, and thus draw the implication that an equal allocation of burdens in tackling challenge would be fair. While this case for the non-legitimacy of the existing distribution of wealth requires more historical detail than there is space for here, let me offer two provisional reasons in support of it.

First, many past interactions of states prior to the existence of the above global institutions continue to have present effects on the global distribution of wealth, e.g. colonization, the slave trade and unjust wars. It follows that the distribution of global wealth cannot be said to have been fully legitimated by adequately regulated interactions between states. Secondly, institutions of global governance have not always complied, and still may not fully comply, with a plausible standard of legitimacy. Consider one criterion that Buchanan and Keohane (2006) propose as part of their "complex standard" of institutional legitimacy: the comparative benefit criterion - or, the criterion that the institution in question should be superior to a feasible alternative institution that can be established without excessive transition costs (see fn. 19 above). Arguably, a feasible alternative structure exists to the WTO and to the Security Council, for example, that might enable poorer or weaker states to better represent their trade and security interests within these institutions. ${ }^{25}$ The

mentioned earlier, however, the institutional view does not rest on the Hobbesian view but a qualified view that allows that some actions outside of legitimate institutions can give rise to duties. So, the institutional view could allow that some state actions today can give rise to later historical duties even if "core" global institutions are not legitimate.

${ }^{25}$ For an elaboration of the two reasons I mention in this paragraph, see Pogge (2008, 18-26). 
legitimacy of the WTO and the Security Council is therefore compromised. Given these two reasons, it is doubtful that the presence of institutions of global governance has provided the necessary background conditions for the emergence of a fully legitimate distribution of global wealth.

Let me emphasise that no particular principle for allocating climate-related burdens follows from the conclusion that the current distribution of global wealth cannot be regarded as fully legitimate. The conclusion I want to draw is more modest: those states with greater wealth cannot appeal to the fact that they have a right to their greater wealth as an objection against a wealth-based principle of burden allocation. ${ }^{26}$ The institutional view thus offers support for the wealth-based interpretation, not by providing a positive case for it, but by removing a powerful objection to it. Note, however, that this is precisely the support that the wealth-based interpretation needs. Common-sense morality tells us to assume as a default position that we should allocate the burdens of tackling common challenges according to wealth and that we should depart from this default position only if those with greater wealth have a full right to it. The support the wealth-based interpretation needs, then, is some argument for why no such full right to wealth can reasonably be asserted. This is precisely what the institutional view provides.

\footnotetext{
${ }^{26}$ The conclusion I am drawing here is similar to a conclusion defended by Simon Caney $(2010,216)$ Notice, however, that Caney justifies the absence of entitlement to full wealth by appealing to the historic wrongs of excessive emissions or deforestation, whereas I justify the absence of entitlement to full wealth by appealing to the fact that wealth accumulation, to date, has not taken place against sufficiently just background conditions.
} 


\section{Acknowledgments}

I am grateful to Charles Beitz, Siba Harb, Jeffrey Howard, Jose-Luis Marti, Lasse Nielsen. Serena Olsaretti, Tom Parr, Isa Trifan, Andrew Walton, Andrew Williams, and two anonymous reviewers for comments on previous drafts of this article.

\section{References}

Bowen, Alex and James Rydge. 2011. "Climate Change Policy in the United Kingdom," OECD, Economics Department Working Papers: 1-42.

Buchanan, Allen and Robert Keohane. 2006. "The Legitimate of Global Governance Institutions.” Ethics \& International Affairs 20 (4): 405-437.

Caney, Simon. 2005. "Cosmopolitan Justice, Responsibility, and Global Climate Change." Leiden Journal of International Law 18: 747-775.

Caney, Simon. 2009. “Human Rights, Responsibilities, and Climate Change.” In Charles R. Beitz and Robert E. Goodin, eds., Global Basic Rights. Oxford: Oxford University Press, pp. 227-247.

Caney, Simon. 2010. "Climate change and the duties of the advantaged." Critical Review of International Social and Political Philosophy 13 (1): 203-228.

Caney, Simon 2012. "Just Emissions.” Philosophy and Public Affairs 40 (4): 255-300.

Duus-Otterström, Göran. 2014. “The Problem of Past Emissions and Intergenerational Debts," Critical Review of International Social and Political Philosophy, 17 (4): 448469.

European Commission 2011. "Emission Database for Global Atmospheric Research." http://edgar.jrc.ec.europe.eu. (accessed May 30, 2018)

Gardiner, Stephen M. 2011. A Perfect Moral Strom: The Ethical Tragedy of Climate Change, Oxford: Oxford University Press.

Gosseries, Axel. 2004. "Historical Emissions and Free-Riding," Ethical Perspectives 11 (1): 
$36-60$.

Houghton, J. T. et. al. 1990. Climate Change: The IPCC Assessment. Cambridge: Cambridge University Press.

IPCC, 2014. "Summary for Policymakers." In C.B. Field et. al., eds., Climate Change 2014: Impacts, Adaptation, and Vulnerability, eds. Cambridge: Cambridge University Press. Jamieson, Dale. 2001. “Climate Change and Global Environmental Justice.” In Clark Miller and Paul N. Edwards, eds., Changing the Atmosphere: Expert Knowledge and Environmental Governance. Boston: MIT Press, pp. 287-308.

Kingston, Ewan. 2014. "Climate Justice and Temporally Remote Emissions.” Social Theory and Practice 40 (2): 281-303.

Locke, John. (1690) 1988. Two Treatises of Government. Ed. P. Laslett. Cambridge: Cambridge University Press.

Long, Graham. 2011. "Disagreement and Responses to Climate Change." Environmental Values 20 (4): 503-525.

Miller, David. 2009. "Global Justice and Climate Change: How Should Responsibilities be Distributed?" Tanner Lectures on Human Values 28: 119-156.

Moellendorf, Darrel. 2012. "Climate Change and Global Justice.” Wiley Interdisciplinary Reviews: Climate Change 3 (2): 131-43.

Neumayer, Eric. 2000. "In Defense of Historical Accountability for Greenhouse Gas Emissions," Ecological Economics, 33 (2): 185-192.

Page, Edward. 2011. "Climatic Justice and the Fair Distribution of Atmospheric Burdens: A Conjunctive Account." The Monist, 94 (3): 412-432.

Page, Edward. 2012. "Give it up for Climate Change: A Defence of the Beneficiary Pays Principle," International Theory 4 (2): 300-330.

Pavel, Carmen. 2016. "A Legal Conventionalist Approach to Pollution," Law and Philosophy 
35 (4): $337-363$.

Pogge, Thomas. 2008. World Poverty and human Rights, Cambridge: Cambridge University Press.

Rawls, John. 2005, Political Liberalism: Expanded Edition, New York: Columbia University Press.

Rawls, John. 2008, Lectures on the History of Political Philosophy. Ed. S. Freeman, Cambridge, MA: Harvard University Press.

Risse, Mathias. 2012. On Global Justice, Princeton, NJ: Princeton University Press.

Seglow, Jonathan. 2013. Defending Associative Duties, London: Routledge.

Shue, Henry. 1999. "Global Environment and International Inequality,” International Affairs 75 (3): $531-45$.

\section{Biographical information}

Paul Bou-Habib is a Senior Lecturer in Political Theory in the Department of Government at the University of Essex, Colchester, CO4 3SQ, United Kingdom. 